\title{
The Origin of Technical Drawing in the Narmer Palette
}

\author{
Adriana Rossi ${ }^{1}$
}

Published online: 22 July 2016

(C) Kim Williams Books, Turin 2016

\begin{abstract}
Over 5000 years ago, together with the proto-hieroglyphics that helped to understand the events recorded in bas-relief, there also appeared, as we will demonstrate, a technical "description" of the plan for a fortified city wall that, though schematic, provided sufficient elements to perform a mathematical calculation of form and structure. Properly illuminated and enlarged, the image, according to the manner and technology used, allows for measurement, justifying the representative and configurative choices of the methodologically deduced threedimensional model. Comparison with the remnants of structures of the same age and the geographic location of the relic supports and confirms such decisions.
\end{abstract}

Keywords Origin of the plan - Initial forms of technical drawings .

Calculation of crenellated walls $\cdot$ Drawing of fortified citadels · Elements of obsidian defense

\section{Introduction}

During the excavations carried out in Hiérakonopolis, Egypt, archeologists unearthed a shield shaped plate of siltstone $(42 \times 64 \times 2.5 \mathrm{~cm})$ with engravings on both sides, the so-called Narmer Palette. The dimensions were too cumbersome for it to be considered a palette of the type used to mix cosmetics. It is more likely

Adriana Rossi

adriana.rossi@unina2.it

1 Dipartimento di Ingegneria Civile Design Edilizia e Ambiente (DIcDEA), Seconda Università degli Studi di Napoli (SUN), Real Casa dell'Annunziata, Via Roma 29, 81031 Aversa, CE, Italy 

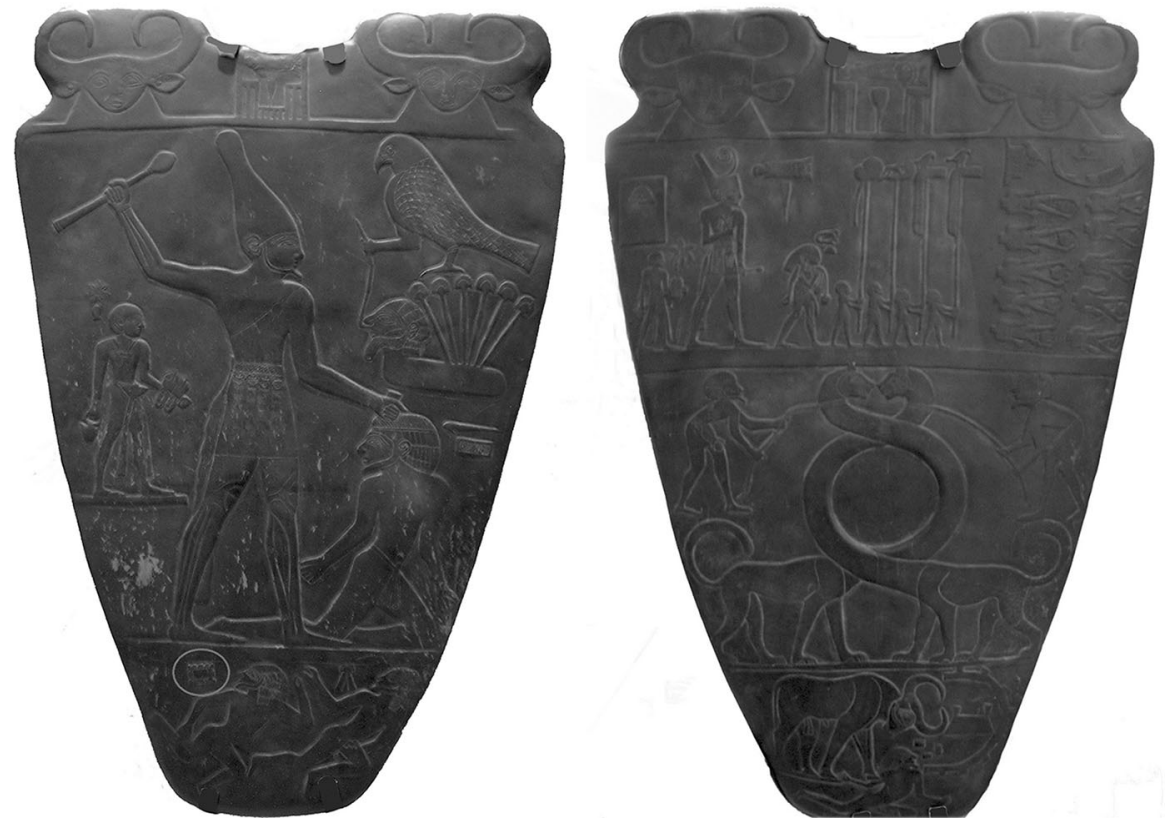

Fig. 1 Front and back of the Narmer palette, 31st c. BC (circa), siltstone $64 \mathrm{~cm} \times 42 \mathrm{~cm}$. Present location: Egyptian Museum, Cairo (identification: Cairo J. E. 14716, C.G. 32169). The area on the front that is the focus of this present research is shown circled. Photo reproduced by permission of the Royal Ontario Museum of Toronto (Canada)

that it was a ceremonial palette, as it was found among objects preserved in the "main deposit" of the Temple of Horus (Fig. 1). ${ }^{1}$

There is no doubt on the other hand regarding the purpose of the engravings: to celebrate the actions of the mythical king Horo-Narmer, also known as Menes, who died in 3125 B.C., the pharaoh to whom history attributes the unification of the kingdoms of Upper and Lower Egypt (Cervelló-Autuori 2005; Grimal 1988).

In observing the incision in light of iconological commentaries, the Ethiopian features of the persons decapitated after their fortresses have been breached and conquered are obvious. ${ }^{2}$ Two of these strongholds are located on the exterior sides of the palette; in front is engraved an enclosure that historians believe may be a fortified citadel (Fig. 2a) ${ }^{3}$; on the rear of the palette is the pharaoh, depicted as a bull charging and destroying the walls (Guy 1992) (Fig. 2b).

\footnotetext{
${ }^{1}$ Found between 1898 and 1899 by British archaeologists James E. Quibell and Frederick W. Greennel (Quibell 1898).

2 The palette displays the classic conventions of Egyptian art that had already been formalized when the item was made. The king, in fact, appears on both sides of the palette, on one side wearing the crown of Lower Egypt and on the other the crown of Upper Egypt (Schulman 1991).

3 “.... and a second rectangular symbol that has no clear interpretation but which has been suggested may represent a town or citadel" (Janson and Janson 1986: 56).
} 

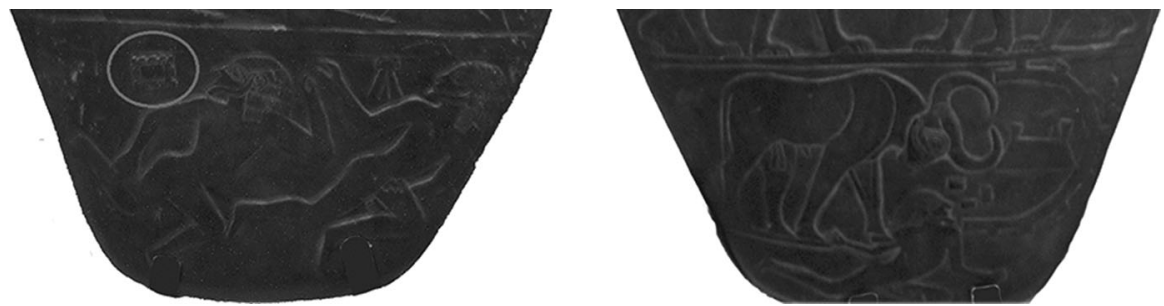

Fig. 2 Narmer palette. a Front detail, with the part that is the subject of this study circled; b back detail

\section{Iconographic Description and Deductions}

The Narmer Palette is a tablet of greenish-grey siltstone, a stone that because of its fine grain and relative hardness allows for meticulous incisions, as in the present case (Cervelló-Autuori 2003; O'Connor 2011). Aided by the excellent lighting of the photograph and a suitable enlargement (Fig. 3), the present study focuses on an area located at the bottom and measuring barely $25 \times 30 \mathrm{~mm}$. Rectangular in shape, the perimeter that encloses an area of approximately $9 \mathrm{~cm}^{2}$, it displays obvious signs of 12 projecting reinforcements, of which four are inserted at the summits, in an axial position, and the remaining for on the longer sides. These are not of equal size, as the larger ones are located at the centre of the short sides.

The enlargement of the photograph allows us to appreciate other minutely etched features, the engraver no doubt being an expert craftsman. At the base of the reinforcements there is a slim light strip; the difference in shading suggests a continuous base that forms a $45^{\circ}$ angle. At the top, on the other hand, is a double line, probably a running parapet that continues along the perimeter, following the outline of the corners and suggesting a narrow passage with behind a surface area indicated by variations in a greyish tonality.

This present research maintains that the rectangular symbol, defined by some as "not easily identifiable" (Janson and Janson 1986: 56), is in reality an aerial view of a fortified structure similar to those erected along the Nile as a defense against the raids of neighboring populations not completely subjugated by Pharaoh Narmer, who reigned between 3150 and 3125 B.C. (I Egyptian dynasty). This assertion is supported by the following considerations:

- The protrusions from the perimeter are not of the same width, which they would be if they had been simple buttresses of the city walls.

- On the rooftop there are narrow passages near the corners, no doubt necessary for reinforcement, betrays their function as avan-corps (a sort of proto-tower) to be used for defense of the flank.

- On the basis of the previous consideration, the parapet adhering to the perimeter creates a sort of 'place d'armes' on the projections, in perfect contiguity and continuity with those that appear on the glacis of the previously identified 'corridor'.

- The thickness of the parapet in relation to the width of the glacis and the place d'armes behind, provides an initial clue to help us measure the structure. 


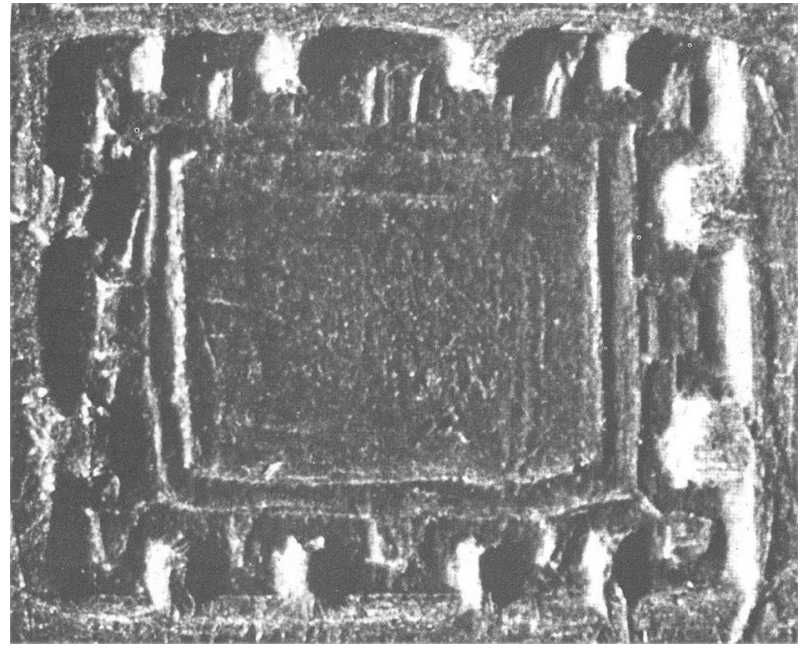

Fig. 3 Magnification used for the analysis in the present study

- The greater size of the buttresses, recognized by their function as flank defense, avan-corps or proto-towers, near the center of the short sides, indicates the presence of machicolations, each placed in a symmetrical and opposing position to prevent anyone from entering.

- The graphic reconstruction shows the twelve protrusions located along a scarp wall having a $45^{\circ}$ inclination, confirming the defensive nature of the structure. The escarpment, in fact, in addition to preventing any siege ladders from being positioned, allowed the stones falling from the walls to bounce, transforming their vertical drops into deadly horizontal trajectories.

- The strongholds (Cassi Ramelli 1964), confirming the function of the architectural elements, transform the image into a series of signs similar to the drawing of a proportioned "imprint", obtained by removing elevations from the plan, in this case the siltstone palette, thereby "flattening" volumes without deforming them. ${ }^{4}$

- By eliminating the depth and maintaining directions and angles, since the point of observation was infinitely far away, it is possible to measure the shapes, achieving plausible results because they are in an exact and unaltered scale relationship.

- Considering the informative purpose of the ornaments etched on the shield (and this regardless of whether it is a palette for cosmetics or a ceremonial palette) we deduce that the method was extremely ancient and so often repeated as to be known to many: not only did the engraver not have any uncertainties, but those

\footnotetext{
4 A 15,000-year-old graffiti engraved on a fragment of ivory has been recognized as the plan for a Paleolithic settlement (Gladkih et al. 1984). In view of the numerous proofs found starting from that date, it is evident that the idea of "flattening" space, and consequently the concept of a vision from afar that was abstract but global, dates to a very remote and primitive past (Docci and Migliari 1992: 74).
} 
who were tasked with decoding the image had to be able to identify precise and clear messages and data.

- The era to which the relic is attributed and the area in which it was found provide reliable information on the period and geography of the events celebrated, directing the research to similar works of the same era for inductive verification of the observations.

\section{Configuring the Reconstruction}

With the module gleaned from the plan, we proceeded to a two-way correspondence to assess the relic in elevation in order to obtain the unit of measurement in the decimal metric system, necessary to determine the geometric rationality of the projections in mathematical multiples and submultiples. The correspondence of the vertical projection (elevation and vertical section) with the respective plans cut at the most significant heights, as occurs with the double orthogonal projections method, has provided a scientific basis for a computerized construction of the threedimensional model. The graphic reconstruction of the most explicatory view led to an additional verification, this time regulated by the method of parallel projections. The isometric orthogonal axonometric view, that is the default view obtained by a virtual projection of the mathematical model constructed on screen controls relations and proportions by simulating tri-dimensionality (Figs. 4, 5, 6, 7, 8).

In the sections that follow, we will show the research that provided support for this reconstruction.

\section{Considerations for the Reconstruction of the Plan}

Contrary to structural solutions, which never strayed outside of a very limited repertory, the shapes formed by the perimeter walls of Egyptian fortresses, even among those of the same era, display a great morphological variety, due to the need to adapt to different sites and to exploit such opportunities by adapting to tactical borders in order to improve defense. There ensue plans that are trapezoidal, rectangular, polygonal and even triangular, as shown by reconstructions of the fortresses of Kor, Mergissa, Dabenarti, Askut, South Semna, lost because submerged by the waters of Lake Nasser, an artificial reservoir that has eroded unfired bricks (Figs. 9, 10). The ruins of Shafalk on the other hand have been spared total disintegration as it is located on what today has become an island.

A comparison of the survey drawings and the reconstructive drawings of the ancient mud walls has led us to believe that the relationship between their height and width is around 1:5, a datum that perfectly concurs with the metric deductions obtained by analyzing the proportions of the turreted perimeter engraved on the Narmer palette. The thickness of the parapet, whose measurements were obtained by considering the approximate encumbrance of a single brick and its placement in rows, is estimated to be $90-120 \mathrm{~cm}$, a size congruous with the width of the rear 
A. Rossi

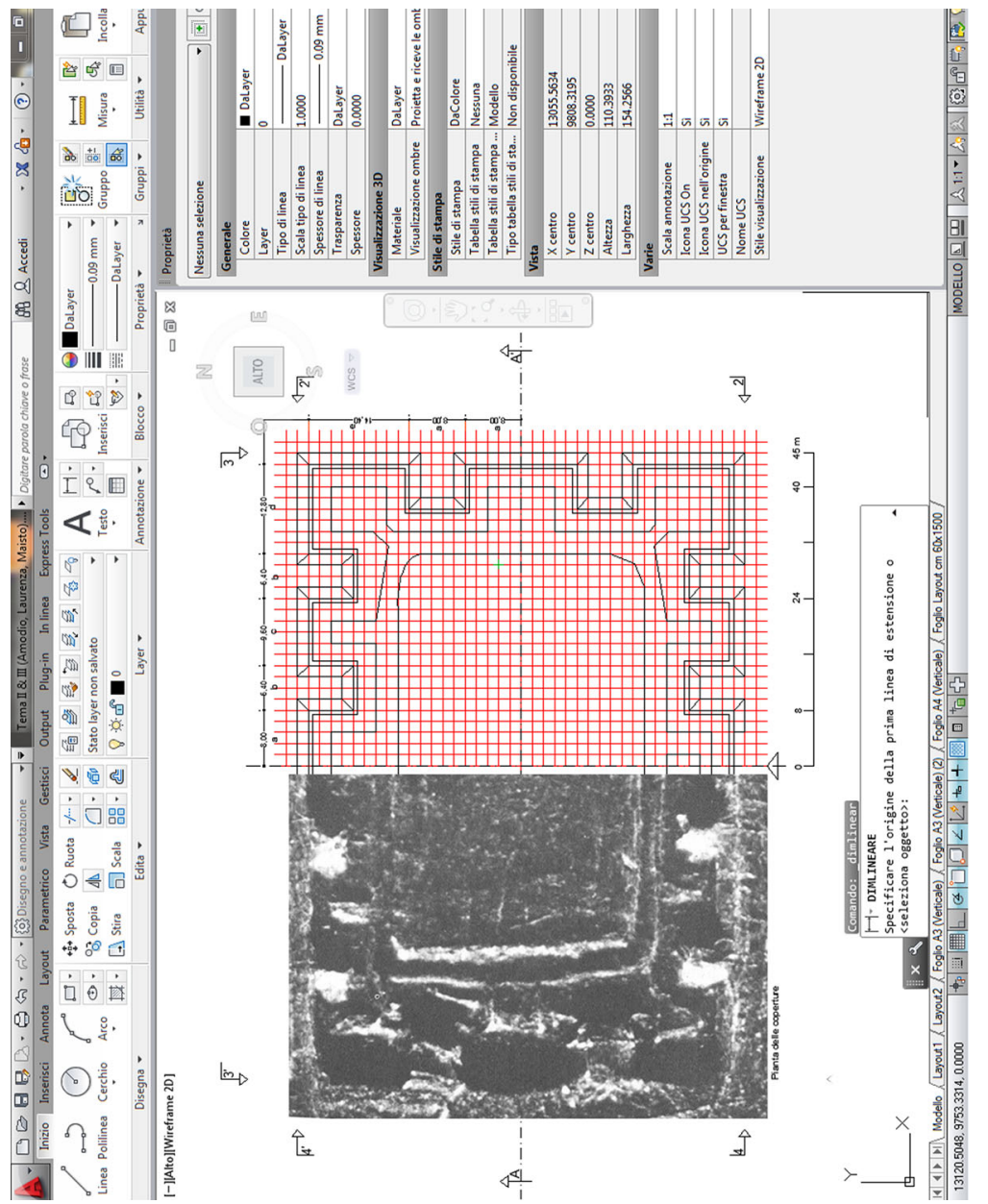

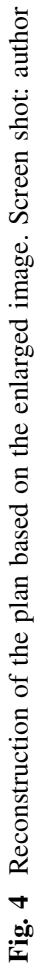



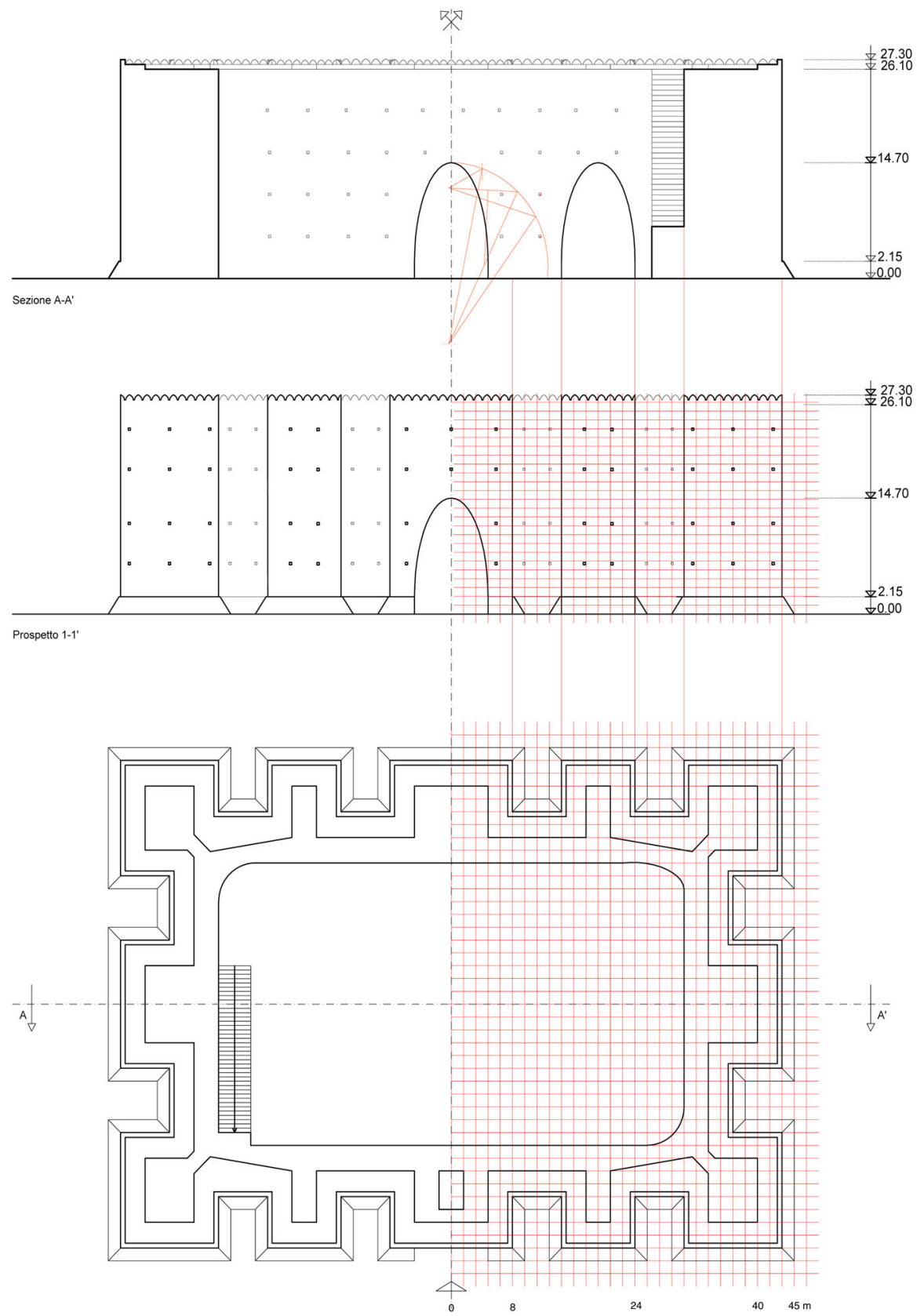

Fig. 5 Hypothetical reconstruction of the fortress: top section A-A; centre elevation 1-1; bottom plan. Image: author 

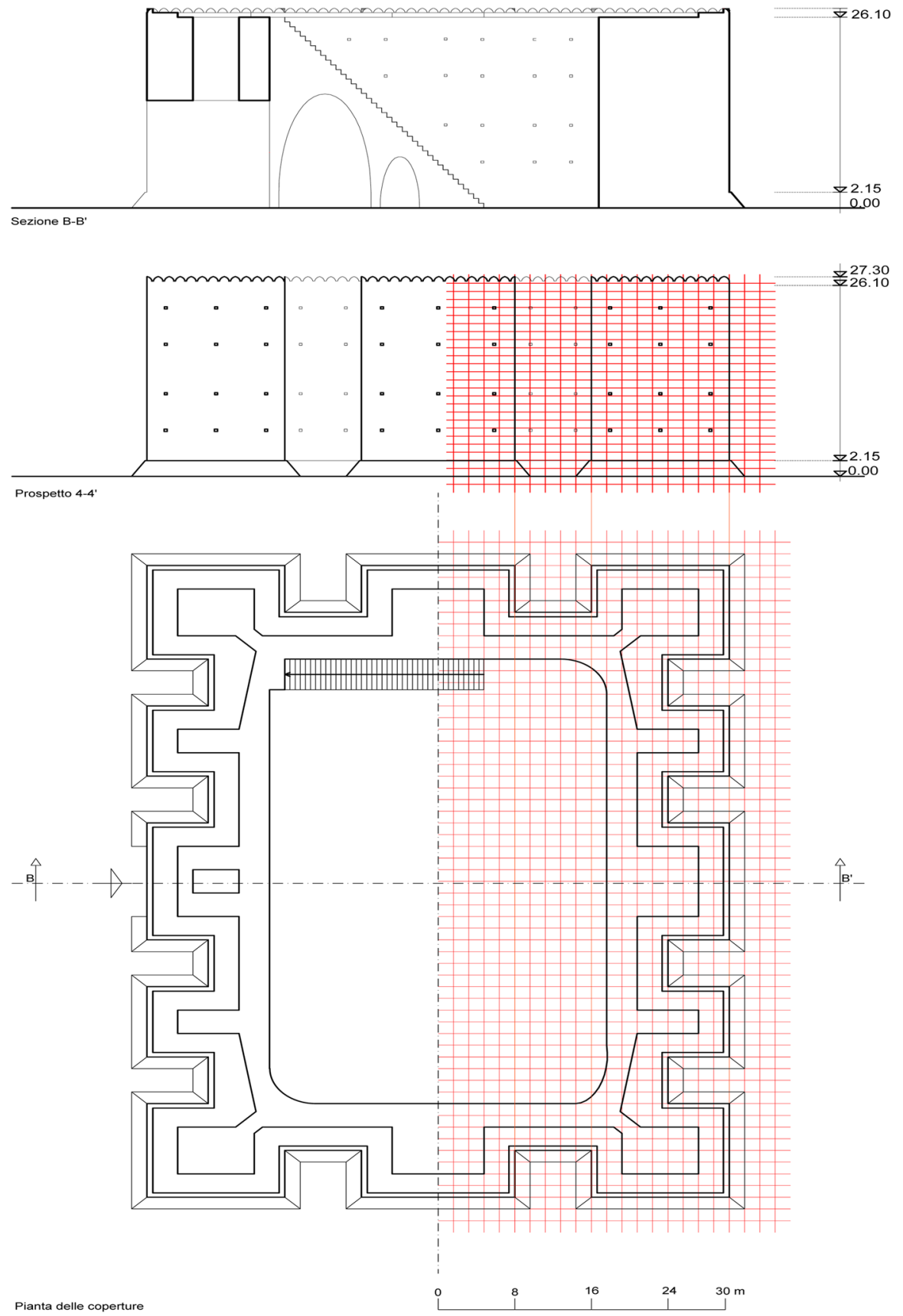

Fig. 6 Hypothetical reconstruction of the fortress: top section B-B; centre elevation 4-4; bottom plan. Image: author 


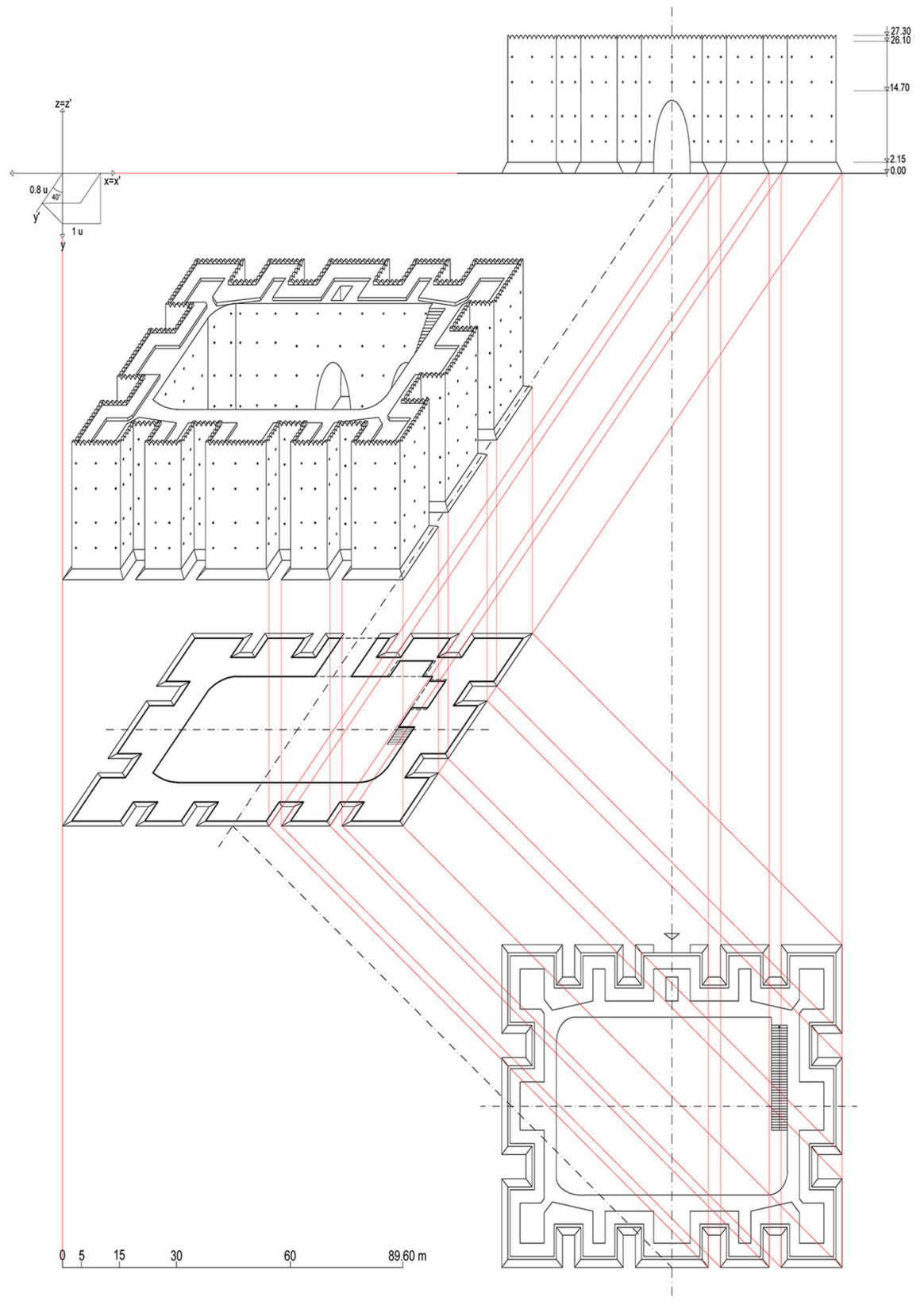

Fig. 7 Hypothetical reconstruction of the fortress: oblique axonometric. Image: author 


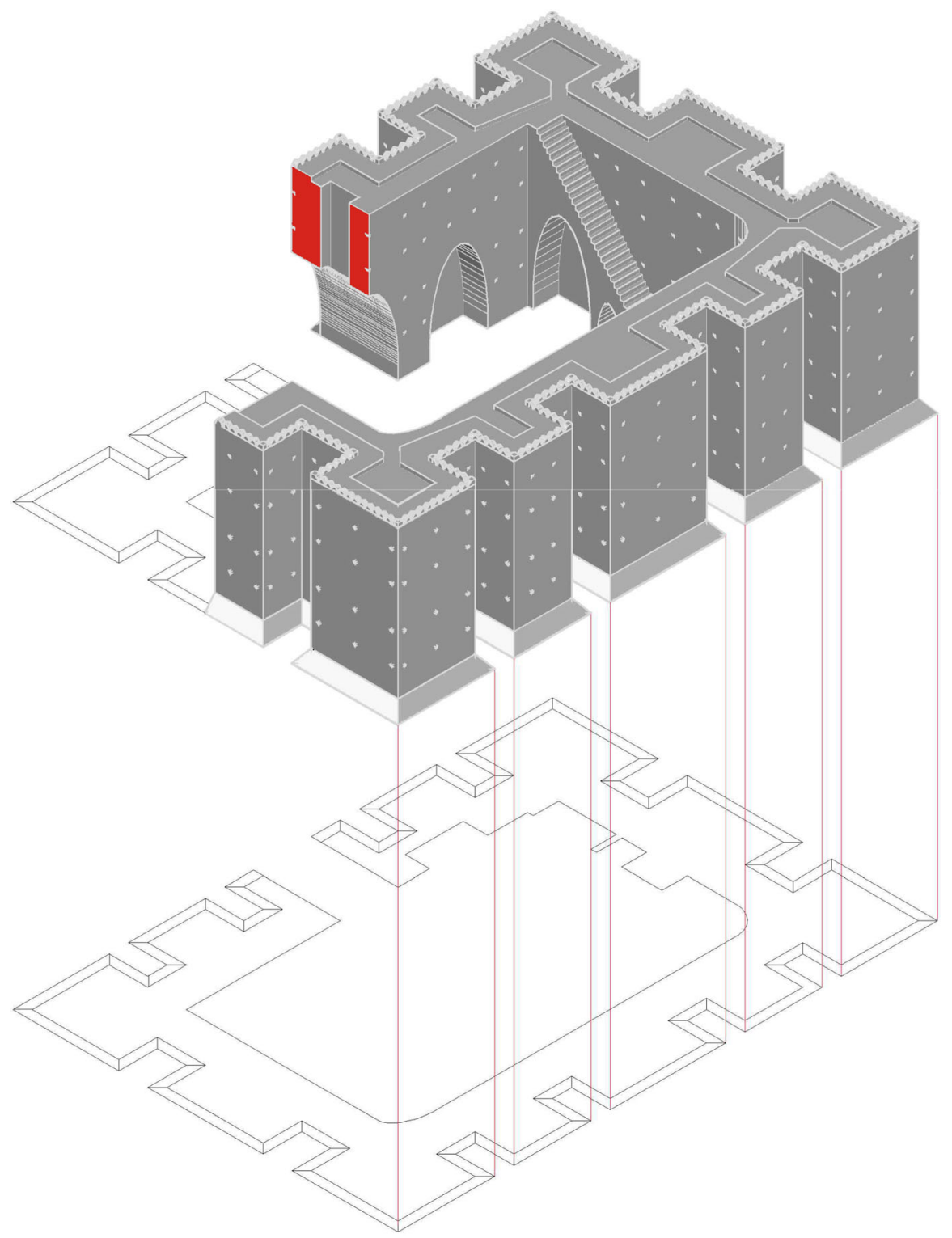

Fig. 8 Hypothetical reconstruction of the fortress: isometric axonometric and rendering. Image: author

glacis that, in turn, can be considered to be double and thus around $2.50 \mathrm{~m}$. By adding the partials, the overall width of the wall at the top is $4 \mathrm{~m}$. An approximate value that can be corrected by other clues offered by the same relic to restrict the margin of error initially calculated to be around $20 \%$.

To this end we analysed the ratios required to calculate: (a) the escarpment that extends for approximately $3.60 \mathrm{~m}$ toward the exterior; (b) the buttresses, from which we have deduced an interaxis of $5 \mathrm{~m}$ and a length of $7 \mathrm{~m}$ along the long sides, 

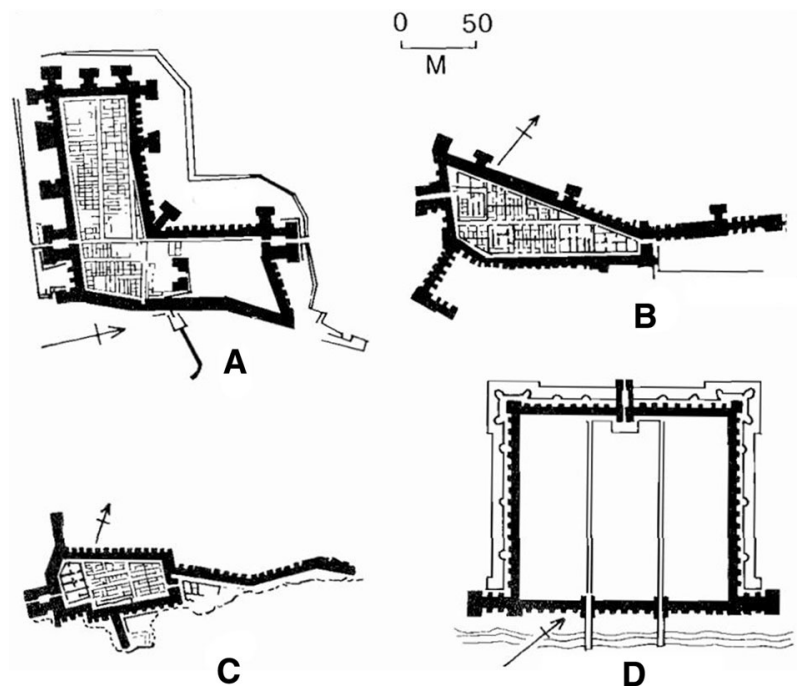

Fig. 9 Plans of Egyptian fortresses: a South Semna; b Uronart; c Shalfak; d Middle Kingdom. Images: author, after (Adams 1977: Fig. 28)

doubled in the center of the short sides; (c) the other measurements were taken as geometrical unit multiples and submultiples, from a grid correlated to Egyptian feet and later resolved into the decimal metric system. Verification is provided by analogous examples, when even if constructed at a later date, are nevertheless plausible because of the very slow evolution at the time of siege tactics due to the unchanged use of telekinetic (rope) weapons. Among the best documented is the Buhen fortress, the archaic border outpost near the second cataract of the Nile, roughly constructed by Amenemhat II (1928-1895 B.C.), completed by Sesostris III and reinforced several times during the early centuries of the reign of Narmer (Breasted 1906: 90-116; Shaw 1991: 20; Emery et al. 1976).

\section{Considerations of Materials for Reconstructing the Elevation}

Having ascertained and accepted that this is the plan for a fortified citadel, we may now consider the elevation. The relief on the Narmer Palette tells us nothing regarding heights, with the exception of the height of the glacis whose graphic reconstruction reveals it to be equal to the horizontal projection, as it was inclined at $45^{\circ}$. Some elements may be obtained from the depiction of the staircase that goes from the internal piazza to the upper glacis. Nevertheless, since we do not know the size of the risers (a variable size in military works) there is no way to gauge the overall height.

Therefore, in order therefore to obtain the height from the drawing of the transcribed plan using the method of double orthogonal projections we referred to the estimates resulting from the mathematical-structural sizing based on data regarding material. 


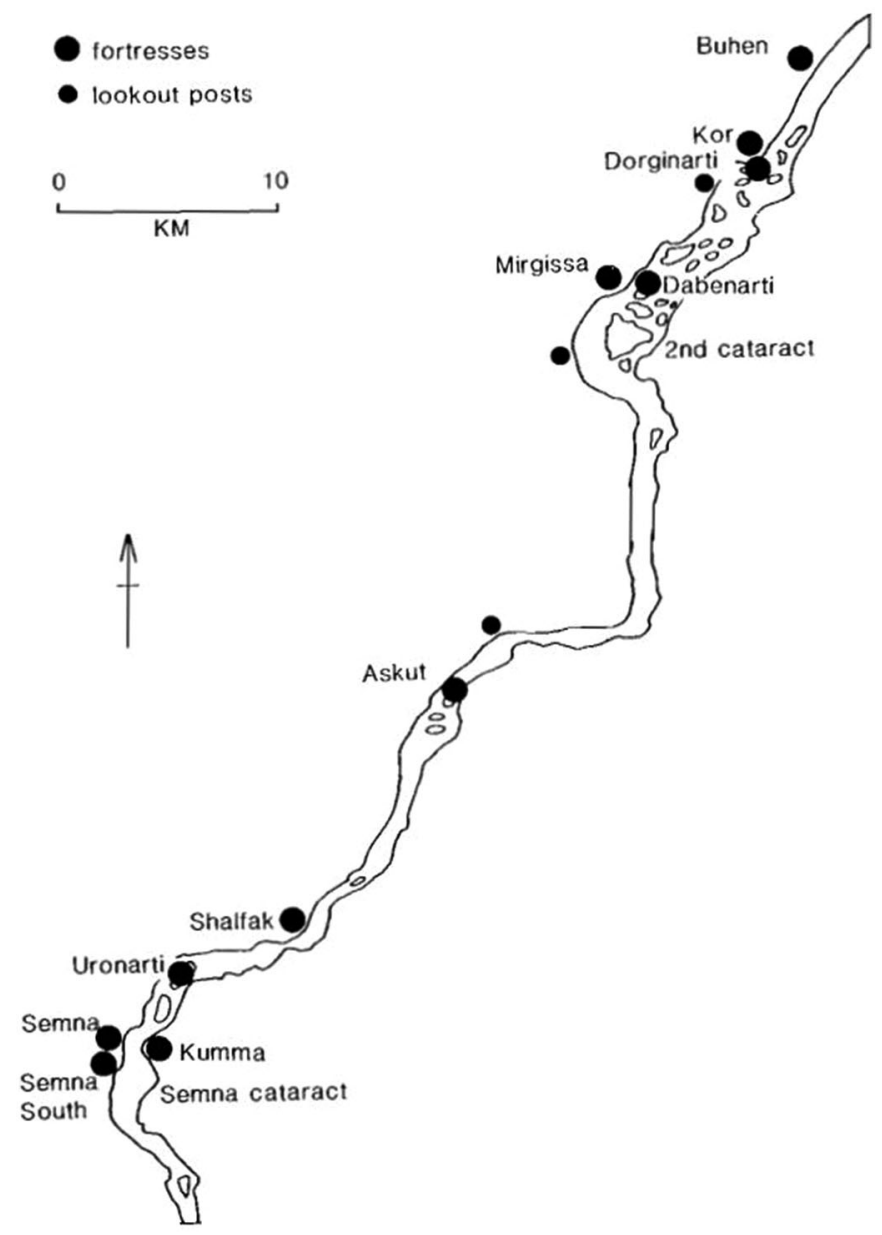

Fig. 10 Map of the second cataract fortresses from Buhen southwards. Image: author, after (Adams 1977: Fig. 27)

In light of conflict between criteria (Hogg 1981), we must first take note of the fact that the purpose common to all fortified walls was the need to allow the besieged garrison to survive in the event of a siege or of the cruel hostilities of the climate and the enemy, which on an architectural level means the need to raise a fairly high wall, closed on all sides, with one or two protected openings. For this reason, in the most evolved archetypes they conceived of proto-towers with glacis that had crenellated parapets and open machicolations to protect the openings. The lodgings and storage sites required for survival were made in the thickness of the walls, while the cisterns to collect rain water were located below. Inside was a courtyard in which the besieged could move about freely and access the highest points of the fortification. 
In order to do this they needed a great quantity of material for the construction, which leads to the legitimate question of how they were able to obtain this material at low cost, achieving the maximum result with a minimum of effort.

It is well known that in Egypt and Mesopotamia, as was true in many of the Middle Eastern fluvial civilizations, the principal ingredient required to build large or small structures, came from the Nile and especially from the Tigris and Euphrates as they provided abundant mud (Sauvage 1998), the dried clay of which is a noncombustible material and provides good thermal insulation and above all it has a moderate mechanical resistance. ${ }^{5}$ The characteristics of rammed earth were well known in the past as they are today. ${ }^{6}$

The custom of pressing mud in small formworks (some examples of which have been found inside Egyptian tombs) to make blocks that were then set out to dry in the sun, as there was no wood for furnaces, is well documented. The perfectly shaped blocks were reinforced with straw or reeds. ${ }^{7}$ The bricks were then positioned into the masonry over a coating of hot bitumen, as they did not have sufficient lime, again because of the lack of wood and stone, while a modest amount of bitumen floated on the waters of the river (Rondelet 1839: 46ff.). The bricks were then laid in even rows. ${ }^{8}$ The whole was perfectly suited to meet the structural needs of the most severe military and civilian architecture.

The most reliable data is available from the technical specifications of a brick manufacturing company that proposes three different types, specifying both the technical characteristics and the flattening deformation values:

1. Heavy bricks of unfired earth made by molding soft paste with mixtures of clayey silt particles and small size vegetable fiber ... cleansed of waste from

\footnotetext{
5 "A wall of unfired bricks is very healthy for those who live within, completely impervious to fire and little disturbed by earthquakes; on the other hand, unless it is reasonably think, it will not be capable of bearing the weight of the flooring" (Alberti 1988: III.ix, 77).

${ }^{6}$ Le pisé est une manière de construire en terre, qui est encore plus simple que celle de bâtir en briques crues. ... Lorsque les murs en pisé sont bien faits, ils ne forment qu'une seule pièce, et lorsqu'ils sont revêtus à l'extérieur d'un bon enduit, ils peuvent durer plusieurs siècles. ... Toutes les terres qui ne sont ni trop grasses, ni trop maigres, sont propres à faire le pisé. Pour préparer la terre, il faut l'écraser et la faire passer par une claie moyenne pour en extraire les pierres qui excéderaient la grosseur d'un noix. ... Lorsque la terre est préparée, on la jette dans une espèces de moule, ou encaissement mobile, où elle est battue par des ouvriers avec un pilon, etc. (When walls in mud are well made, they comprise a single piece, and when they are coated externally using a good plaster can last for several centuries ... All soil that is neither too loamy nor too dry, is suitable for construction using the mud method. To prepare the soil it must be cut into small pieces and sieved to remove any stones larger than a nut.... When the soil is ready, it is placed in a sort of press or movable formwork, where it is beaten by laborers using a pestle, etc.) (Rondelet 1812: 228-30); see also Rondelet 1839: 46ff). In our own day in Italy Law 378, dated 24 December 2003, was issued to safeguard and promote various types of architecture representative of traditional rural economy. There are also many well organized associations that work to foster, disseminate and develop the techniques and culture linked to unfired clay.

7 The proportions of the construction components vary according to local tradition. In our own era, the following formula is recommended to make $1 \mathrm{~m}^{3}$ of mixture: $1 \mathrm{~m}^{3}$ of soil, $1 \mathrm{~m}^{3}$ of water, $0.23 \mathrm{~m}^{3}$ of straw (equal to $47.5 \mathrm{~kg}$ ) (Achenza and Sanna 2009).

8 There is a vast bibliography on this topic. For a full explanation of the methods used to analyze numerous buildings we refer to studies by the founder of a construction science, Jean-Baptiste Rondelet (1812-1817).
} 
previous processes, dried mechanically using a controlled system (approx. 10 days), in lots of $45 / \mathrm{m}^{2}$ (thickness $15 \mathrm{~cm}$ ). Size $5.5 \times 15 \times 29 \mathrm{~cm}$ (with $5 \mathrm{~mm}$ tolerance per lot), dry weight ca. $3.5 \mathrm{~kg}$, density ca. $1450 \mathrm{~kg} / \mathrm{m}^{3}, \lambda$ $0.47 \mathrm{~W} / \mathrm{mK}, \mu$ 8. Compression resistance $2.9 \mathrm{~N} / \mathrm{mm}^{2}$.

2. Semi heavy bricks of unfired earth ... made by molding soft paste with mixtures of clayey silt particles and small size vegetable fiber ... cleansed of waste from previous processes, dried mechanically using a controlled system (approx. 10 days), in lots of $45 / \mathrm{m}^{2}$ (thickness $15 \mathrm{~cm}$ ). Size $5.5 \times 15 \times 29 \mathrm{~cm}$ (with $5 \mathrm{~mm}$ tolerance per lot), dry weight ca. $2.9 \mathrm{~kg}$, density ca. $1200 \mathrm{~kg} / \mathrm{m}^{3}, \lambda$ $0.40 \mathrm{~W} / \mathrm{mK}, \mu$ 7. Compression resistance $3.9 \mathrm{~N} / \mathrm{mm}^{2}$.

3. Light bricks of unfired earth ... made by molding soft paste with mixtures of clayey silt particles and small size vegetable fiber ... cleansed of waste from previous processes, dried mechanically using a controlled system (approx. 10 days), in lots of $45 / \mathrm{m}^{2}$ (thickness $15 \mathrm{~cm}$ ). Size $5.5 \times 16 \times 30 \mathrm{~cm}$ (with $5 \mathrm{~mm}$ tolerance per lot), dry weight ca. $2.2 \mathrm{~kg}$, density ca. $800 \mathrm{~kg} / \mathrm{m}^{3}, \lambda$ $0.18 \mathrm{~W} / \mathrm{mK}, \mu$ 5. Compression resistance $4.2 \mathrm{~N} / \mathrm{mm}^{2}$.

According to the restrictive regulations in Turkey, a country in which bricks are still produced, the maximum admissible load is barely $1 \mathrm{~N} / \mathrm{mm}^{2}$, equal to $102 \mathrm{~g} /$ $\mathrm{mm}^{2}$, or $10.2 \mathrm{~kg} / \mathrm{cm}^{2}$.

Transferring the data of the three types of bricks considered, there would be a resistance in the first case of $29 \mathrm{~kg} / \mathrm{cm}^{2}$; in the second $39 \mathrm{~kg} / \mathrm{cm}^{2}$ and in the third $42 \mathrm{~kg} / \mathrm{cm}^{2}$.

Results are confirmed by the those deduced from tests, necessary because of the lack of a specific regulation. The results obtained in several Italian laboratories calculate, for unbaked bricks, an average compression resistance of $2.59 \mathrm{~N} / \mathrm{mm}^{2}$ (in contrast to $5.91 \mathrm{~N} / \mathrm{mm}^{2}$ for baked bricks ${ }^{10}$ ), a value that coincides with the quantity certified by the company making the heavy bricks (Germanà and Panvini 2008: 229ff.). For purposes of our study, considering the difference between the various types, we have taken into account the lesser amount, so as to have an admissible load of ca. $29 \mathrm{~kg} / \mathrm{cm}^{2}$, a result not disproven by laboratory tests carried out in other regions (Achenza and Sanna 2009).

Using this information to analyze the ancient plan engraved on the Narmer Palette, we conclude that:

- The structure was made using bricks of unfired earth; there are numerous remains and documents confirming this assumption;

- The fortified wall did not exceed 20-30 m in height;

- the compression resistance of the unfired bricks was sufficient and did not require any special measures save for appropriate insulation to obstruct the humidity rising from the soil, in our case provided by the stone escarpment;

\footnotetext{
${ }_{9}$ Extracted from "Voci di Capitolato" of Laterizi Brioni s.r.1., http://www.fornacebrioni.it/capitolato. pdf.

${ }^{10}$ Burnt bricks have a resistance that is $4-5$ times greater, estimated to be approximately $400 \mathrm{~kg} / \mathrm{cm}$ compared to the $50 \mathrm{~kg} / \mathrm{cm}$ for unburnt brickwork, the threshold limit for permanent deformation and certainly not for breakage.
} 
- the installation in parallel rows of 2, 3 and 4 bricks provides an approximate sizing of the thickness of those multiple parts of the walls made of standard brick. Some of the most common measures were $1 \times 1 \mathrm{ft}$, circa $30 \times 30 \mathrm{~cm}$, or $1 \times 0.5 \mathrm{ft}(30 \times 15 \mathrm{~cm})$ (Rondelet 1839: 104ff).

These determinations were then verified inductively by comparing the data obtained with drawings of the relics or iconographic documents of fortresses built to defend the Egyptian kingdom in the appropriate period of time. For this purpose we used as typological reference for the reconstructive hypothesis the funerary complexes destined to function, in the event of attacks, as defensive walls. Specifically, because of the analogies it has with the subject of our study, the wall placed as protection of the Temple of Osiris at Khasekhemwy (Abydos). The main wall is $12 \mathrm{~m}$ high, $6 \mathrm{~m}$ thick at the base and $5 \mathrm{~m}$ thick at the top. The wall was protected by a $5 \mathrm{~m}$ high external enclosure, with a horizontal gap of $3 \mathrm{~m}$. The facades documented are smooth and uniform: apart from the doors there is no other opening similar to those of future centuries such as slits and machicolations (Shaw 1991).

In line with this analysis, the reconstruction of the elevation does not have any 'ornaments', with the exception of the rows of holes for the scaffolding posts removed at the conclusion of the works. Concerning the sections, on the other hand, it was necessary to theorize solutions that were technically functional and compatible with the material used and with the technology that allowed for construction using unfired bricks.

\section{Hypothesizing the Arched Shapes of Vaults and Openings}

If the art of building walls using unbaked bricks was learned slowly, that of constructing vaults and opening arcs with radial joints was an invention that marked the progress of construction technology (Huerta 2007: 213). Before in fact, they first had to learn that bricks remained stable and in position when being laid one on top of the other thanks to the force of gravity. This knowledge made it possible to cover spaces with corbelled stones forming successive rings. The origins of what we today call "false cupolas" are lost to time immemorial; but proof of their existence are found in several sites of Asia Minor and Europe, such as the trulli found in the Puglia region of Italy.

The early uses of vaulting in Egyptian architecture has been discussed in (Huerta 2007: 212-217), and provides us with sufficient reason to hypothesise its use in our reconstruction. Vaults allowed for a homogeneous distribution of loads and greater freedom of movement at the base. For this reason in our reconstruction even the sections used to support the stair is parabolic. Compared to other equally symmetrical forms such as ovals and ellipses, a 'balanced' catenary allowed for homogeneous distribution of compression loads without using piers or support element, of the type found on the gates of Hattusa, with a width of ca $3 \mathrm{~m}$ and a height of ca. $5 \mathrm{~m}$ (Neve 1992). 


\section{Conclusions}

The analysis demonstrates that the image studied is the "imprint" of a fortified perimeter of the type erected to protect the Egyptian kingdom of the XXXII c. B.C. The ability to conceive and design a layout, still legible today in proportional ratios and graphic conventions, and in spite of the millennia that have passed, confirms an intuitive practice that boasted of a time-tested tradition.

What makes this icon original for its type resides in the minute description of the details that, once illuminated and appropriately enlarged, allow for an objective interpretation of specific expedients of military architecture.

For those who are familiar with the historical metamorphosis of methods of representation and conventional signs, the conventional system of lines used is sufficient to envision the function of the individual parts (among themselves and in relation to the whole) such as to obtain the dimensions required to correlate form and structure mathematically.

The comparison with the remains of works of the era from the same geographic area direct the inductive verification of conclusive considerations.

The crux of the hypothesis is therefore the relationship that links mathematics to architecture, confirmed through graphic reconstructions and constructive geometric modelling. The exercise confirms the intuitive invariance of conventions that allow graphic language to communicate contents that are very controversial when referring to the deciphering of proto-hieroglyphics. By directing the documentation, the study assists in restorations and reconstructions, confirming the importance of measuring, which, by emphasizing 'doing', confirms that architecture can be measured with the help of manual, mechanical, optical and electronic instruments but also through the history of technique and of social relations, theories and geometries issuing from the work and upon which future hermeneutical and critical stratifications are based.

\section{References}

Achenza, Maddalena and Ulrico Sanna. 2009. Caratteristiche tecniche di riferimento degli elementi da costruzione. Pp. 120-123 in: Il manuale tematico della terra cruda, Cagliari: Centro Stampa dell'Università.

Adams, William Y. 1977. Nubia: Corridor to Africa. London: Princeton University Press.

Alberti, Leon Battista. 1988. On the Art of Building. Joseph Rkywert, Robert Tavernor and Neil Leach, trans. Cambridge, MA: MIT Press.

Breasted, James Henry. 1906. Historical Documents from the Earliest Times to the Persian Conquest, 5 vols. Chicago: University of Chicago Press.

Cassi Ramelli, Antonio. 1964. La fortificazione primitiva e dell'antichità. In: Dalle caverne ai rifugi blindati: trenta secoli di architettura militare. Milano: Nova Accademia Editrice (2nd ed., Bari: Mario Adda Editore,1996).

Cervelló-Autuori, Josep. 2005. Was King Narmer Menes? Archéo-Nil 15: 31-46.

Cervelló-Autuori, Josep. 2003. Narmer, Menes and the seals from Abydos. In: Zahi A. Hawass, ed., Egyptology at the Dawn of the Twenty-first Century: Archaeology. Proceedings of the Eighth International Congress of Egyptologists, vol. II, pp. 168-175. Cairo: The American University in Cairo Press. 
Docci, Mario and Riccardo Migliari. 1992. Scienza della rappresentazione. Roma: Nuova Italia scientifica.

Emery, Walter B., Henry S. Smith, Alan R. Millard. 1976. Excavations at Buhen, vol. I. London: Egypt Exploration Society.

Germanà, Maria Luisa and Rosalba Panvini, eds. 2008. La Terra Cruda nelle Costruzioni. Dalle testimonianze archeologiche all'architettura sostenibile (Atti della Giornata di Studi Caltanisetta, Museo Archeologico Santo Spirito, 29 giugno 2007). Palermo: Nuova Ipsa Editore.

Gladkih, Mikhail I., Ninelj L. Kornietz, Olga Soffer. 1984. Mammoth-Bone Dwellings on the Russian Plain. Scientific American 251(5) (Nov. 1, 1984):164-175.

Grimal, Nicolas. 1988. Histoire de l'Egypte ancienne. Paris: Editeur Fayard.

Guy, Rachet. 1992. Dictionnaire de la civilisation ègiptienne. Paris: Larousse librairie.

Hogg, Ian Vernon. 1981. The History of Fortification. London: St. Martin's Press.

Huerta, Santiago. 2007. Oval Domes: History, Geometry and Mechanics. Nexus Network Journal 9(2): 211-248.

Janson, Horst Woldemar and Anthony F. Janson. 1986. History of Art: A Survey of the Major Visual Arts from the Dawn of History to the Present Day, 3rd ed. New York: Abrams.

Neve, Peter (1992). Hattuša - Stadt der Götter und Tempel: neue Ausgrabungen in der Hauptstadt der Hethiter (2nd ed.). Mainz: P. von Zabern.

O’Connor, David (2011). «The Narmer Palette: A New Interpretation» i: Teeter, E.: Before the Pyramids, Chicago: Oriental Institute of the University of Chicago, pp.145-152. ISBN 13: 978-1-885923-82-0.

Quibell, James Edward. 1898. Slate Palette from Hierakonpolis. Zeitschrift für ägyptische Sprache und Altertumskunde (Z.A.S.) 36: 81-84.

Rondelet, Jean-Baptiste. 1812-1817. Traité théorique et pratique de l'art de bâtir. 7 vols. Paris: Hachette Livre.

Rondelet, Jean-Baptiste. 1839. Trattato teorico e pratico dell'arte di edificare. It. trans. with notes by Basilio Soresina. Naples: Tipografia del Gallo.

Sauvage, Martin. 1998. La brique et sa mise en oeuvre en Mésopotamie: des origines à l'époque Achéménide. Paris: Centre de Recherche d'Archéologie Orientale.

Schulman, Alan R. 1991. Narmer and the Unification: A Revisionist View. Buletin of the Egyptological Seminar 11: 79-105.

Shaw, Ian. 1991. Fortresses and frontiers. Pp. 15-24 in: Egyptian Warfare and Weapons. Buckinghamshire: Shire Publications.

Adriana Rossi earned her Master's degree in Architecture (1984) with honors. She successfully completed her $\mathrm{PhD}$, she was awarded a post-doctorate scholarship, and after she qualified as a confirmed Researcher as of 2002, she has been Associate Professor of Survey and Graphic Representation. Her didactic activity has focused on the graphic fundamentals of architectural configurations which have converged with her research objectives consisting in two main goals: implementing knowledge through graphing representation and making the most of such resources for design purposes. The results achieved have been published in articles, monographs and conference proceedings which have been recorded in the research census of the university web site. 